\title{
EXPLORATORY STUDY OF THE INTEGRATION OF FRUGAL INNOVATION IN THE DESIGN OF PRODUCTS FOR THE BOP
}

\author{
López Santiago, Luis Miguel (1); Rohmer, Serge (1); Díaz Pichardo, René (1,2); Reyes, Tatiana \\ (1)
}

1: Université de Technologie de Troyes, France; 2: South Champagne Business School, France

\begin{abstract}
The bottom of the pyramid (BoP) consists of 1.4 billion people living less than 1.25 USD per day. Fulfilling unmet needs of BoP people involves the design of products as a main activity. Designing products for the BoP faces two main problems. First, there is a general lack of understanding of the needs of users and second, traditional design methods may be limited in addressing the BoP context. Frugal innovation is positioned as a very interesting approach with the potential to adequately respond to the design challenges of the products for the BoP. However, studies in engineering design based on frugal innovation are still limited. In response to these issues, through an analysis and review of the literature, an exploratory mapping of the proposals in frugal innovation and the characteristics of the $\mathrm{BoP}$ was conducted. On the basis of the results, this paper defines a set of eight frugal criteria design and an identification of three dimensions that characterize a BoP context and two roles of BoP people. Finally, an association of BoP dimensions and roles with the key criteria of frugal design is proposed.
\end{abstract}

Keywords: New product development, Design process, Design engineering, Frugal Innovation, Bottom of the Pyramid (BoP)

Contact:

López Santiago, Luis Miguel

University of Technology of Troyes, France

HETIC - CREIDD

France

luis_miguel.lopez_santiago@utt.fr

Cite this article: López Santiago, L.M., Rohmer, S., Díaz Pichardo, R., Reyes, T. (2019) 'Exploratory Study of the Integration of Frugal Innovation in the Design of Products for the BoP', in Proceedings of the 22nd International

Conference on Engineering Design (ICED19), Delft, The Netherlands, 5-8 August 2019. DOI:10.1017/dsi.2019.338 


\section{INTRODUCTION}

In 2015, close to 46 percent of the world's population was living on less than $\$ 5.50$ a day and still struggles to meet basic needs (World Bank, 2018). Prahalad (2005) introduces the term "Bottom of the Pyramid (BoP)" to refer to this segment of the population and suggests a potential market for multinational companies if they develop products and services for them. Most of the BoP literature has been developed in the management and economics areas, while few studies have been done in the area of design (Kolk, Rivera-Santos and Rufín, 2014). Although the BoP studies are based on the market approach (Casado Cañeque and L. Hart, 2015), satisfying needs while developing business involves the design of products as a main activity (Jagtap et al., 2014). Currently, the design of products for the BoP faces two main problems. First, there is a general lack of understanding of the needs of BoP users, which conditions the success or failure of the products (Chandra and Neelankavil, 2008; Grover, Caulfield and Roehrich, 2014). Second, traditional problem-solving methods such as those used in industrial and engineering design may be limited in addressing the BoP context. This could confuse the design team by proposing suitable solutions for the BoP (Castillo, Diehl and Brezet, 2012). Recently, a phenomenon of innovation has appeared in low-income and in high-income countries (Seyfang and Smith, 2007). This phenomenon is known as Frugal Innovation (FI) and emerges as an approach that challenges the traditional paths of innovation (Rosca, Arnold and Bendul, 2017). FI involves (re)designing products, services or systems to significantly reduce costs without sacrificing user value especially in low-income settings (Bhatti, 2012; Rao, 2013). FI is positioned as a very interesting approach with the potential to adequately respond to the design challenges of the products for the BoP. However, FI has not reached a theoretical maturity in the literature and studies in engineering design are still limited (Rosca, Arnold and Bendul, 2017). In this context, it is necessary to scrutinize the literature in order to better understand the design strategies of FI and its relationship with the BoP approaches.

The present study is guided by two questions that seek to identify firstly, which are the frugal innovation criteria that make a product suitable for the $\mathrm{BoP}$ and secondly, which are the characteristics of the BoP market that allow to better understand users' needs. This led to an exploratory mapping of the existing proposals for frugal innovation and the characteristics of the BoP based on an analysis and review of the literature. The results of this analysis were a set of eight key design criteria based on frugal innovation strategies (Affordability, Availability, Acceptability, Awareness, Aspirational, Functionality, Scalability and Sustainability), a three-dimensional proposal (setting, cognitive and relations) and two roles (Consumer and Producer) that can help designers characterize a BoP context and finally, a relation between the key frugal design criteria with the $\mathrm{BoP}$ dimensions.

Following this introduction, the rest of the document is organized as follows: Section 2 presents the current context of the design for the BoP and its relationship with frugal innovation. Section 3 presents the research approach used. Section 4 shows the results of the literature analysis, i.e., eight frugal innovation design criteria, a three-dimensional proposal and two roles for characterize a BoP and the relation between these criteria and dimensions. Section 5 presents a summary, perspectives and some limitations. Finally, section 6 presents conclusions and future work of this investigation.

\section{DESIGNING FOR THE BOP}

\subsection{Challenges in BoP design}

The key statement and definition of the "Bottom of the Pyramid" concept is that poverty can be alleviated through economically profitable activity (Prahalad, 2005). This concept has generated great controversy in the economic development literature and other related areas (Kolk, Rivera-Santos and Rufín, 2014). The profit opportunities in the BoP context are modest at best and a cautious approach is suggested. In practice, the characteristics of each industry will influence what type of business will develop between a given company and the poor in order to generate a profit for anyone involved in the process of product development (WBCSD, 2004). As reported by Karnani (2007), the best opportunities to create profit exist when the firm reduces the price significantly by innovatively changing the price-quality trade-off in a manner acceptable to the poor. The studies carried out by Damas and Md. Israt (2004) and Merwe et al. (2017) propose that the reduction of poverty, from the perspective of for-profit organizations is achieved by proposing products that better meet the basic physical and psychological needs of poor people. Understanding the BoP is fundamental in the research carried out for engineering design. However, 
proposing products for the $\mathrm{BoP}$ requires facing restrictions significantly different from those of the developed markets (UNDP, 2008). According to Chandra and Neelankavil (2008), many of the design flaws in BoP contexts are due mainly to the lack of understanding users' needs. Companies often lack detailed information about the markets in which the poor live and are often considered as quite "dark" areas in terms of the information available (Gradl et al., 2008). As a consequence, engineers who are designing products must use different approaches to solve problems since the demands, needs and cultural aspects of BoP contexts are very different from that of developed markets (Shekar and Drain, 2016). Historically, the publication "Design for the Real World" by Victor Papanek (1972) is considered the precursor of the design for the BoP. Papanek's proposal challenged designers to develop products for low-income economies and go beyond traditional proposals purely profit oriented. Likewise, Schumacher's (1973) approach known as "Appropriate Technology (AT)" describes that large-scale technologies and their transfer from high-income to low-income countries were largely inappropriate. This has been considered as the historical roots of frugal innovation (Rosca, Reedy and Bendul, 2018).

\subsection{Frugal innovation in BoP contexts}

The term frugal innovation emerges as "for-profit appropriate technology", emphasizing the role of the for-profit private sector as a key partner for innovation in the global, contemporary and development economy (Kaplinsky, 2011). The new paradigm of FI goes beyond the market approach and challenges traditional ways of innovation that go from the generation of ideas, rethinking the production processes and also the business models (Prabhu, 2017). Currently, the FI approach has allowed the development of solutions in different sectors (Transport, Healthcare, Water, Bank, Energy, etc.) and in the formal and informal markets (Levänen et al., 2016; Rosca, Reedy and Bendul, 2018). Bhatti's studies (2012) conclude that FI is a label that captures a range of heterogeneous activities and to consider a product, service, practice or process as a FI, the conditions demanded by each of the two components must be met. The frugal aspect involves solving needs without being hindered by affordability, resources or institutional constraints. The innovation aspect implies innovating in one of the intersections of technological, institutional and social innovation. Academics and practitioners have proposed many interesting definitions that involve the BoP. For Gupta (2012), FI is a philosophy of management that integrates the needs of BoP markets as a starting point in the development of solutions. FI can be an innovative design process in which users are the key approach to developing accessible, adaptable, affordable and appropriate products (Basu, Banerjee and Sweeny, 2013). For Agarwal et al. (2017) FI is an affordable "Good-enough" product that meets the needs of consumers with limited resources. Current definitions help to better understand FI and its BoP related aspects. However, to date, criteria have been needed to clearly define frugal innovation (Weyrauch and Herstatt, 2017), particularly in the area of engineering design of $\mathrm{BoP}$ products. To this is added the constant problem about the lack of understanding of the BoP needs by designers (Shekar and Drain, 2016). With this context, we argue that, firstly, an identification of the most important criteria of FI will allow designers to have clues to improve the BoP product design process. Second, a better understanding of BoP market systems will help designers better identify people's needs to design appropriate products. More generally, this will help create an initial proposal of how to relate the BoP market to a design process based on FI.

\section{RESEARCH METHODOLOGY}

In order to answer the questions raised in the introductory part, an analysis and extensive review of the literature has been carried out based on the proposals of Jill, Matheson and Lacey (2011). Regarding the level of analysis, this study focused on the macro and meso levels (Della Porta and Keating, 2008; Given, 2008). The macro level refers to the study of the generalities of Frugal Innovation as well as the $\mathrm{BoP}$ approaches and strategies, both from the perspective of different disciplines. At the meso level is the identification and grouping of frugal design criteria proposed by the authors, without including the analysis of the characterization or the way to evaluate these criteria (micro level analysis).

There are two major steps in the research methodology:

\section{State of the art in frugal innovation strategies and BoP innovation.}

The definition of the research questions was based on the description of the introductory section. The search protocol included the terms "frugal innovation" and "BoP Innovation" in the title, abstract or list of keywords. We considered three main databases: Science Direct, Scopus, and Web of Science, then, we selected the journals where most of the contributions were identified. Because FI is a recent 
phenomenon, there was no restriction in the year of publication. A good overview was presented by some review papers (Castillo, Diehl and Brezet, 2012; Pansera and Martinez, 2017; Weyrauch and Herstatt, 2017; Hossain, 2018; Pisoni, Michelini and Martignoni, 2018).

\section{Identification of frugal design criteria and BoP characteristics.}

Because the BoP keyword opens up an immense academic debate in several areas of study, we analyse "BoP" by "Keywords-in-context"(Onwuegbuzie, Leech and Collins, 2012) with the surrounding words as "design and frugal" to delimit the scope of our research. Articles describing the characteristics of a frugal innovation at the product level were priority. Once identified the characteristics of FI, those that are similar were combined and added in a single list of design criteria. Based on "Human Centered Design" methods and tools such as those proposed in (IDEO.org, 2015), (Lockton, Harrison and Stanton, 2010) and (van Boeijen, 2015), each criteria was transformed into an basic design question at product level (Table 2). The analysis of the BoP was based on the concept of "Social Capital" initially proposed by Nahapiet and Ghoshal (1998) and retaken by Vallejos et al. (2008), Faccin, Genari and Macke (2017). Frugal innovation definitions argue a close relationship between BoP characteristics and frugal product design. In order to make an initial association BoP-FI, we assigned a frugal design key criteria to a BoP dimension or role (Table 5), this association is justified by what was found in the literature.

\section{RELATING FRUGAL INNOVATION DESIGN CRITERIA WITH BOP CONTEXTS}

This study was delimited at a macro-meso level. The following subsections will detail the main results presented below:

- A set of eight frugal key criteria and basic design questions based on FI strategies.

- An identification of dimensions and roles that characterize a BoP context.

- An association of BoP dimensions and roles with the key criteria of frugal design.

\subsection{Frugal innovation criteria and BoP design questions}

Advances in FI research have generated many definitions that allow identifying the main characteristics of a FI. The first focuses on product-level characteristics and is defined as: "Good-enough," affordable products that meet the needs of resource-constrained consumers (Agarwal et al., 2017). The second one is described as an Innovation process design in which customers are the key focus to develop accessible, adaptable, affordable, and appropriate products (Basu, Banerjee and Sweeny, 2013). The third one is presented as a Management philosophy which integrates the needs of the $\mathrm{BoP}$ market as a starting point to develop solutions (Gupta, 2012). The analysis and review of the literature resulted in Table 1 in which the desirable characteristics of frugal and BoP innovations are identified according to different authors.

Table 1. Characteristics of "BoP products and Frugal Innovations."

\begin{tabular}{|l|l|l|}
\hline \multicolumn{1}{|c|}{ Author } & $\begin{array}{l}\text { Desirable Characteristics (BoP products, Frugal } \\
\text { Innovations) }\end{array}$ \\
\hline 1 & (Schumacher, 1973) & $\begin{array}{l}\text { Technical Feasibility, Social Acceptability, Resources } \\
\text { Availability, Economic Affordability, Favourable } \\
\text { Institutions, Environmental Sustainability }\end{array}$ \\
\hline 2 & (Rogers, 1983) & $\begin{array}{l}\text { Relative Advantage, Compatibility, Complexity, Trialability, } \\
\text { Observability. }\end{array}$ \\
\hline 3 & (Prahalad, 2005) & Affordability, Access, Availability, Scalability \\
\hline 5 & (Anderson and Markides, 2006) & Affordability, Availability, Acceptability, Awareness \\
\hline 6 & (Richardson and Callegari, 2008) & Affordability, Availability, Accessibility \\
\hline 7 & (Mashelkar, 2014) & Affordability, Simplicity \\
\hline 8 & (Angot and Plé, 2015) & $\begin{array}{l}\text { Affordable Access, Financial Sustainability, High Quality } \\
\text { Goods and Services, Empowerment of the excluded } \\
\text { population, Massive Outreach }\end{array}$ \\
\hline 9 & $\begin{array}{l}\text { (Whitehead, Evans and } \\
\text { Bingham, 2016) }\end{array}$ & $\begin{array}{l}\text { Affinity, Desirability, Reparability, Durability, Functionality, } \\
\text { Affordability, Usability, Sustainability }\end{array}$ \\
\hline 10 & (Weyrauch and Herstatt, 2017) & Cost reduction, Functionality, perform well \\
\hline
\end{tabular}


In the Table 1 there are some characteristics that are mentioned by more than one author while other features are unique. Anderson and Markides (2006) establish important factors for BoP innovations and identified four essential elements for a product to be successful in these markets. Similar proposals were made by Prahalad (2005) and Richardson and Callegari (2008). This set of strategies is known as the "4As" and is described as follows:

- Affordability: an innovation must be affordable by even the poorest consumers.

- Availability (Accessibility): innovation must be easily available to the BoP market,

- Acceptability: innovation must be compatible with social norms and existing local values.

- Awareness: most of BoP consumers can not be reached by conventional advertising media, so new ways of reaching customers should be considered.

The works of Rogers (1983) in conjunction with "Appropriate Technology" proposed by Schumacher (1973) were the first to raise the criteria that should characterize products for low-income markets. Their proposals suggest paying special attention to the social, cultural and ethical aspects of the communities to which the technology is intended. The criteria of Financial Sustainability and Environmental Sustainability can be aggregated in a single dimension as Sustainability. The characteristics such as High Quality, Complexity, Technical Feasibility, Resources Availability emphasize that a product must be of good quality but at the same time manufactured with available resources and local infrastructure, this implies that a product must be functional, i.e., simple in use, operation, and manufactured with high quality criteria. Massive Outreach and Scalability emphasize that products must be sold and distributed in different BoP markets, so "Scalability" can group these characteristics. Mashelkar (2014) mentions that the empowerment of the excluded population can be achieved if the products help to raise the perception of poor people in society, i.e., contribute to their aspirations.

In summary, at least eight key characteristics of a FI for the BoP were identified: Affordability, Availability, Acceptability, Awareness, Aspirational, Functionality, Scalability and Sustainability. Given that the designer also has a role as a decision maker during the BoP product design process, integrating each of these criteria is an important and complex task. From the list of characteristics, a set of basic questions was formulated in order to guide the designer to integrate the criteria of FI into a product for a BoP market (Lockton, Harrison and Stanton, 2010; IDEO.org, 2015; van Boeijen, 2015).

Table 2. Frugal design key criteria and related design question.

\begin{tabular}{|c|c|}
\hline Frugal Design Key Criteria & Basic question for a BoP product (designer's point of view) \\
\hline Affordability & Is the product or the innovation affordable for local users? \\
\hline Availability & Is the product available to all users in different areas? \\
\hline $\begin{array}{l}\text { Acceptability } \\
\text { (Affinity) }\end{array}$ & $\begin{array}{l}\text { Will the users accept the product without compromise their } \\
\text { cultural, customs and social local norms? }\end{array}$ \\
\hline Awareness & $\begin{array}{l}\text { How can users learn about the existence and benefits of the } \\
\text { product? }\end{array}$ \\
\hline $\begin{array}{l}\text { Aspirational } \\
\text { (Empowerment of the excluded } \\
\text { population, Desirability) }\end{array}$ & $\begin{array}{l}\text { Is the product desirable for the users? } \\
\text { Is the product something users will be proud to own? } \\
\text { Will the product improve people living standards? }\end{array}$ \\
\hline $\begin{array}{l}\text { Functionality } \\
\text { (High Quality Goods and Services, } \\
\text { Complexity, Reparability, } \\
\text { Technical Feasibility, Resources } \\
\text { Availability, Durability, Simply, } \\
\text { perform well, Functionality, } \\
\text { Usability) }\end{array}$ & $\begin{array}{l}\text { Are the functions of the product adequate? } \\
\text { Does the product employ resources locally available? } \\
\text { Is the product easy to understand and use correctly by low } \\
\text { literacy people? } \\
\text { Is the product robust enough to work in the local environment? } \\
\text { Can the product be maintained and repaired locally? }\end{array}$ \\
\hline $\begin{array}{l}\text { Scalability } \\
\text { (Massive Outreach) }\end{array}$ & $\begin{array}{l}\text { Can the product be replicated to reach others contexts and more } \\
\text { users? }\end{array}$ \\
\hline $\begin{array}{l}\text { Sustainability } \\
\text { (Financial and Environmental } \\
\text { Sustainability) }\end{array}$ & $\begin{array}{l}\text { Does the product consider environmental impacts in terms of } \\
\text { material choice and end of life? } \\
\text { Can the product generate profits in the short and long term? }\end{array}$ \\
\hline
\end{tabular}

This list of eight key criteria for FI is a relevant beginning for the identification of design factors at the product level. Similarly, questions formulated from these previously identified criteria can help designers make decisions during the design process. 


\subsection{Characteristics and dimensions of the BoP}

The number of factors influencing the BoP analyse is obviously very large. Yet they all need to be taken into consideration while searching for appropriate solutions, as they are interdependent. Integrating all factors means researching and implementing innovations, at several fronts in a particular socioeconomic context, to address the unmet needs of the BoP community (Kandachar and Halme, 2008). A better understanding of the BoP market will help designers to identify and understand better BoP needs. More broadly, it will help us to understand how productive BoP market systems evolve generally (Dionisio, 2016). Traditional approaches study BoP from a marketing point of view, but BoP can be considered a social structure with its own characteristics that go beyond being a low-income market. Social Capital is a fruitful theoretical perspective for understanding the norms and social relations embedded in the social structures of societies (Narayan and Cassidy, 2001; Vallejos et al., 2008). According to Nahapiet and Ghoshal (1998) there are three main dimensions that can characterize a social structure: Structural, Relational and Cognitive. Vallejos et al. (2008) identify elements that constitute each of these dimensions, for our study one of the most important elements is proposed as "Setting". From the analysis of the literature, a list of most representative characteristics of the BoP was obtained, then they were classified in one of the three dimensions proposed by the Social Capital theory (Table 3).

\section{Table 3. BoP Dimensions - Characteristics}

\begin{tabular}{|l|l|}
\hline Dimension & BoP characteristics \\
\hline Setting & $\begin{array}{l}\text { People live in rural and urban areas. Poor people live in discomfort, in unhygienic, } \\
\text { dangerous, dirty, badly service, and often polluted environments where they are } \\
\text { vulnerable to many physical shocks, stresses and afflictions (Narayan, 2002). }\end{array}$ \\
\hline Cognitive & $\begin{array}{l}\text { Strong but diverse orientation on culture, traditions and religion. Sense of belonging to a } \\
\text { specific group or tribe (Letelier, Flores and Spinosa, 2003). Feelings of powerlessness, } \\
\text { dependency, low self-esteem, low literacy (Basu, Banerjee and Sweeny, 2013). }\end{array}$ \\
\hline Relations & $\begin{array}{l}\text { Strong social orientations, high importance of persona relationships. Often organized in } \\
\text { social networks. (Chambers, 1995; Narayan, 2002)People are rapidly becoming } \\
\text { connected and networked (Prahalad, 2005). The typical family tends to be larger, } \\
\text { stressed gender relations (Banerjee and Duflo, 2007) }\end{array}$ \\
\hline
\end{tabular}

In addition to the proposed BoP dimensions, it is essential to consider that the study in the BoP literature has had two generational approaches, the first one is focused on the people of the BoP as consumers and the second as producers (Kolk, Rivera-Santos and Rufín, 2014; Dionisio, 2016; Merwe et al., 2017). These two roles allow to understand the people of the BoP from the economic and marketing point of view. These roles also have characteristics that influence the design process of a product (Jagtap and Larsson, 2018). Table 4 summarizes the characteristics associated with each role of the BoP.

Table 4. BoP Roles - Characteristics

\begin{tabular}{|l|l|}
\hline Role & BoP Stakeholders characteristics \\
\hline Consumer & $\begin{array}{l}\text { Low literacy but brand and value-conscious consumers (Prahalad, 2005). Significant } \\
\text { unmet needs (L. Hammond et al., 2007). Variability in income (Banerjee and Duflo, } \\
\text { 2007). Products are purchased on an as needed basis (Prahalad, 2005). }\end{array}$ \\
\hline Producer & $\begin{array}{l}\text { Entrepreneurial drive and motivation (Prahalad, 2005). Self-employed as a result of a } \\
\text { lack of opportunities (Banerjee and Duflo, 2007). Often described as tired, exhausted } \\
\text { and worn out (Narayan, 2002). Low level of technology and low skilled production } \\
\text { (Banerjee and Duflo, 2007). Significant dependence on informal businesses (L. } \\
\text { Hammond et al., 2007). } \\
\text { Little capital and equipment, lack to organized markets, lack of information access } \\
\text { (Narayan, 2002; L. Hammond } \text { et al., 2007). }\end{array}$ \\
\hline
\end{tabular}

\subsection{Frugal design criteria and BoP dimensions}

The contexts where resources are limited, such as the BoP, provide fertile ground for the development of frugal innovations (Zeschky, Widenmayer and Gassmann, 2011). The results of the two previous sections have been associated in a proposal of integration of the characteristics of the BoP and the way in which these can influence the Key Design Criteria. This association was made based on the definitions of frugal innovation used in this article and in the same way with what was argued by the 
different authors. Table 5 presents and synthesizes at the macro level the "BoP Dimension/role - Key Frugal design criteria" relationship found.

Table 5. Relation frugal design criteria and BoP dimension

\begin{tabular}{|c|l|l|}
\hline $\begin{array}{c}\text { Dimension } \\
\text { Role BoP }\end{array}$ & \multicolumn{1}{|c|}{$\begin{array}{c}\text { Key Frugal Design } \\
\text { Criteria related }\end{array}$} & \multicolumn{1}{c|}{ Influence in design process } \\
\hline Setting & $\begin{array}{l}\text { Affordability } \\
\text { Availability } \\
\text { Aspirational }\end{array}$ & $\begin{array}{l}\text { Understanding of the context in which the product will be } \\
\text { implemented (challenges, difficulties and opportunities) } \\
\text { (Gupta, 2010; Pansera and Sarkar, 2016; Shekar and Drain, } \\
\text { 2016). }\end{array}$ \\
\hline Cognitive & $\begin{array}{l}\text { Affordability } \\
\text { Acceptability } \\
\text { Aspirational }\end{array}$ & $\begin{array}{l}\text { Knowledge and information about the local culture, traditions } \\
\text { (Letelier, Flores and Spinosa, 2003; Castillo, Diehl and } \\
\text { Brezet, 2012; Lecomte, 2015; van Boeijen, 2015). }\end{array}$ \\
\hline Relations & $\begin{array}{l}\text { Availability } \\
\text { Awareness } \\
\text { Scalability }\end{array}$ & $\begin{array}{l}\text { Knowledge about the social orientation and how make } \\
\text { networking with others (Narayan, 2002; Prahalad, 2005; } \\
\text { Simanis } \text { et al., 2008) }\end{array}$ \\
\hline Producer & $\begin{array}{l}\text { Affordability, Awareness } \\
\text { Availability, Scalability } \\
\text { Sustainability }\end{array}$ & $\begin{array}{l}\text { Knowledge and information about local networks, available } \\
\text { material and resources. (Murcott, 2007; UNDP, 2008; Gupta, } \\
\text { 2010; Casado Cañeque and L. Hart, 2015) }\end{array}$ \\
\hline Consumer & $\begin{array}{l}\text { Affordability, Availability } \\
\text { Acceptability } \\
\text { Simplicity }\end{array}$ & $\begin{array}{l}\text { Knowledge and information about their unmet needs and } \\
\text { purchasing power.(Prahalad, 2005; L. Hammond } \text { et al., 2007) }\end{array}$ \\
\hline
\end{tabular}

\section{IMPLICATIONS AND LIMITATIONS}

This study has several implications. The review of the literature has revealed a very strong relationship between the discourses in frugal innovation and the BoP. For its part, BoP studies have been divided into two large generations. A first generation with focus on consumption through the offer of products and services that better fits the needs of the BOP and a second generation based on the development of mechanisms to alleviate poverty. Regarding the BoP studies, most of the literature focused on the areas of business and proposed frameworks, models and initiatives obtained from case studies generally concentrated in a few countries, sectors and companies. Although the recent BoP studies still focus on the management disciplines, there are interesting proposals that can enrich our research. One of them is to stop "targeting" the poor, as clients or as cheap labor, but learn to see them as business partners in the entire corporate value chain(WBCSD, 2004). For its part, frugal innovation is a young discipline and there are at least a dozen proposals that define it, this implies that there should be more interest in explaining the phenomenon, focusing less on giving a definition. Due to the novelty of FI, there is still no theoretical maturity; this has led to research in this field following the same path of research for the BoP, that is, to focus on innovation at the institutional level and the business models. As has been argued in this article, regardless of the BoP's generational study approach, product design is an essential activity to meet the needs of people living in poverty. Table 1 represents a compendium of the different characteristics positioned as desirable in a BOP product. Several of the BoP design strategies have been taken up by the frugal innovation approach and vice versa. This has as a main consequence that there is no clear difference between an innovation for the $\mathrm{BoP}$ and a product designed from the perspective of FI. Table 2 synthesizes in eight unique criteria the key criteria for a design based on frugal innovation and especially oriented to a BoP product. In order to guide the design process, each of these criteria was transformed into an initial reference question that can help the designer make decisions or improve their designs. Although the questions were posed as traditionally proposed by the user-centered design methods, in this stage, this research did not conduct field studies to corroborate the pertinence of the proposed questions. It is important to emphasize that although the 4A's strategy is essential in BoP projects, and that affordability is one of the most important design criteria in a BoP market, it is necessary to analyse in depth the other remaining criteria to define a possible order of integration priority and pertinence of each one during the design process. For Table 3 and Table 4, it was necessary to mobilize the theory of social capital to characterize at a macro level the BoP. This analysis allows to simplify the description of the BoP in three dimensions and two main roles. However, and as mentioned in a reiterated manner, the number of factors that can influence this analysis is very long and beyond the scope of our research. The results presented in Table 5 focused on relating the dimensions and roles of the BoP with the frugal design criteria. This 
relationship needs a microanalysis that has to go beyond the literature review, since including all the dimensions of the BoP in a parallel way in product development is a complex task. However, from the designer's perspective, this could represent a first stage of BoP user integration in a co-design process. In the same way, this study had a series of limitations. As explained in the research methodology, the information and knowledge came exclusively from the literature analysis. While this allows mapping knowledge, concepts, strategies and current criteria in the area of BoP and FI, it is necessary to complete our findings with empirical studies. Another important limitation was the level of analysis of both, the frugal design and innovation criteria and the characteristics of the BoP. This first stage of research was kept at a level mostly macro and meso, and being an exploratory study, this research work opens opportunities for a next stage of field experiments.

\section{CONCLUSIONS AND FUTURE WORK}

The objective of this research is to contribute to a better understanding of frugal innovation and the $\mathrm{BoP}$ for its integration in the design processes. Through an analysis of the literature, eight design criteria representative were identified (Affordability, Availability, Acceptability, Awareness, Aspirational, Functionality, Scalability and Sustainability) and presented in the form of essential BoP design questions. These questions could help designers in making decisions during the product design process for the BoP. Based on the theory of social capital and the literature review of the BoP, three dimensions (setting, cognitive and relations) and two roles (Consumer, Producer) were proposed in order to characterize the BoP contexts and thus help the designers to better understand these markets and their users. BoP contexts are considered interesting terrains for the development of frugal innovations, this leads to the idea that BoP contexts can directly influence how FI criteria are implemented during the product design process. The review of the literature allowed us to make a first association of frugal innovation criteria identified with BoP dimensions and roles previously defined. This relationship needs to be studied in more detail to understand how a BoP context can be properly characterized and how criteria of frugal innovation can be implemented.

The future work involves conducting a deeper analysis of our findings, particularly in what is proposed as Relation BoP Dimensions/roles and frugal design criteria. In order to validate our results, this research work contemplates future experimentation plans with entrepreneurs who are located in BoP contexts, particularly in the development of a medical prosthesis in a Brazilian community and a water access project in Togo.

\section{REFERENCES}

Agarwal, N. et al. (2017), “A systematic literature review of constraint-based innovations: State of the art and future perspectives", IEEE Transactions on Engineering Management, Vol. 64 No. 1, pp. 3-15. https://doi/org/10.1109/TEM.2016.2620562.

Anderson, J. and Markides, C. (2006), "Strategic Innovation at the Base of the Economic Pyramid”, pp. 1-18.

Angot, J. and Plé, L. (2015), "Serving poor people in rich countries: the bottom-of-the-pyramid business model solution", Journal of Business Strategy, Vol. 36 No. 2, pp. 3-15. https://doi/org/10.1108/JBS-11-2013-0111.

Banerjee, A. V. and Duflo, E. (2007), "The Economic Lives of the Poor", Journal of Economic Perspectives, Vol. 21 No. 1, pp. 141-167. https://doi/org/10.2139/ssrn.942062.

Basu, R. R., Banerjee, P. M. and Sweeny, E. G. (2013), "Frugal Innovation Core Competencies To Address Global Sustainability Introduction: A Call For Global Sustainability”, Journal of Management for Global Sustainability, Vol. 2, pp. 63-82. https://doi/org/10.13185/JM2013.01204.

Bhatti, Y. (2012), "What is frugal, what is innovation?" Towards a theory of frugal innovation, Available at: http://ssrn.com/abstract=2005910.

van Boeijen, A. (2015), “Crossing Cultural Chasms, towards a culture-conscious approach to design”. Delft University of Technology. https://doi.org/10.4233/uuid:fc87dfd1-b7eb-4c84-b6c7-6835c5e837f8.

Casado Cañeque, F. and L. Hart, S. (2015), Base of the Pyramid 3.0 Sustainable Development Through Innovation and Entrepreneurship, Greenleaf Publishing, New York, USA.

Castillo, L. G., Diehl, J. C. and Brezet, J. C. (2012), "Design Considerations for Base of the Pyramid (BoP) Projects", Proceedings of the Cumulus Helsinki 2012 Conference, (January), pp. 1-15. Available at: http://cumulushelsinki2012.org/cumulushelsinki2012.org/wp-content/uploads/2012/05/Design-Considerations-forBase-of-the-Pyramid.pdf.

Chambers, R. (1995), "Poverty and livelihoods: Whose reality counts?", Environment \& Urbanization, Vol. 7 No. 1 , pp. 173-204. https://doi/org/10.1177/095624789500700106. 
Chandra, M. and Neelankavil, J. P. (2008), "Product development and innovation for developing countries: Potential and challenges", Journal of Management Development, Vol. 27 No. 10, pp. 1017-1025. https://doi/org/10.1108/02621710810916277.

Damas, P. and Md. Israt, R. (2004), "Vulnerability and Poverty: What are the causes and how are they related?" https://doi/org/10.3917/empa.060.0024.

Dionisio, M. A. (2016), "Evolution of the Base of the Pyramid (BOP) Construct Through a Bi-Dimensional Perspective", European Journal of Business and Social Sciences, Vol. 5 No. 7, pp. 38-50.

Faccin, K., Genari, D. and Macke, J. (2017), "Interorganisational social capital and innovation: a multiple case study in wine producers networks in Serra Gaúcha, RAI Revista de Administração e Inovação”, Departamento de Administração, Faculdade de Economia, Administração e Contabilidade da Universidade de São PauloFEA/USP, Vol. 14 No. 1, pp. 52-66. https://doi/org/10.1016/j.rai.2016.12.002.

Given, L. M. (2008), “The SAGE Encyclopedia of Qualitative Research Methods”. In: L. M. Given (ed.), SAGE Publications Ltd, United States of America. http://doi.org/10.4135/9781412963909.n464.

Gradl, C. et al. (2008), "Understanding the markets of the poor: A market system approach to inclusive business models", Sustainability challenges and solutions at the base of the pyramid: Business, technology and the poor, pp. 30-50. https://doi/org/10.9774/GLEAF.978-1-909493-77-3_3.

Grover, A., Caulfield, P. and Roehrich, K. J. (2014), "Frugal innovation in healthcare and its applicability to developed markets", British Academy of Management, pp. 1-57.

Gupta, A. (2010), “Grassroots Green Innovations for Inclusive, Sustainable Development”, The Innovation for Development Report 2009-2010, pp. 137-146. https://doi/org/10.1057/9780230285477_6.

Gupta, A. k. (2012), "Innovations for the poor by the poor, Int. J. Technological Learning", Innovation and Development, Vol. 5 (February 2010), pp. 28-39.

Hossain, M. (2018), "Frugal innovation: A review and research agenda", Journal of Cleaner Production. Elsevier Ltd, Vol. 182, pp. 926-936. https://doi/org/10.1016/j.jclepro.2018.02.091.

IDEO.org (2015), The Field Guide to Human-Centered Design, Edited by IDEO.org, Canada: IDEO.ORG.

Jagtap, S. et al. (2014), "How design process for the Base of the Pyramid differs from that for the Top of the Pyramid", Design Studies, Elsevier Ltd, Vol. 35 No. 5, pp. 527-558. https://doi/org/10.1016/j.destud.2014.02.007.

Jagtap, S. and Larsson, T. (2018), "Design and Frugal Innovations: Three Roles of Resource-Poor People", in International Design Conference - Design 2018, pp. 2657-2668. https://doi/org/10.21278/idc.2018.0152.

Jesson, J. K., Matheson, L. and Lacey, F. M. (2011), "Doing your literature review: traditional and systematic techniques”, Evaluation \& Research in Education, SAGE Publications Ltd, California. https://doi/org/10.1080/09500790.2011.581509.

Kandachar, P. and Halme, M. (2008), "Farewell to pyramids : how can business and Solutions at the Base of the Pyramid: Bbusiness", Technology and the Poor, Vol. 44 No. 0, pp. 1-27.

Kaplinsky, R. (2011), "Schumacher meets schumpeter: Appropriate technology below the radar", Research Policy, Elsevier B.V., Vol. 40 No. 2, pp. 193-203. https://doi/org/10.1016/j.respol.2010.10.003.

Karnani, A. (2007), "The Mirage of Marketing to the Bottom of the Pyramid, How the private sector can help alleviate poverty", California Management Review, Vol. 49 No. 4.

Kolk, A., Rivera-Santos, M. and Rufín, C. (2014), "Reviewing a Decade of Research on the "Base/Bottom of the Pyramid" (BOP) Concept", Business and Society, Vol. 53 No. 3, pp. 338-377. https://doi/org/10.1177/0007650312474928.

L. Hammond, A. et al. (2007), "The next 4 billion, market size and business strategy at the base of the pyramid". World Resources institute.

Lecomte, C. (2015), "Ingénierie frugale pour les Bases de la Pyramide: Concevoir des produits ouverts pour des contextes multiples", Université de Grenoble. Available at: https://tel.archives-ouvertes.fr/tel-01152729.

Letelier, M. F., Flores, F. and Spinosa, C. (2003), "Developing Productive Customers in Emerging Markets", California Management Review, Vol. 45 No. 4, pp. 77-103. https://doi/org/10.2307/41166189.

Levänen, J. et al. (2016), "Implications of frugal innovations on sustainable development: Evaluating water and energy innovations”, Sustainability (Switzerland), Vol. 8 No. 1, pp. 1-17. https://doi/org/10.3390/su8010004.

Lockton, D., Harrison, D. and Stanton, N. A. (2010), "Design Intent behaviour through design", Requisite Variety. https://doi/org/10.1016/j.bone.2012.05.012.

Mashelkar, R. A. (2014), “Accelerated inclusive growth through Inclusive Innovation”, (April).

Van Der Merwe, M. D. et al. (2017), "The base of the pyramid: towards a high growth framework for sme action", IAMOT 2017 Conference Proceedings, p. 20.

Murcott, S. (2007), “Co-evolutionary design for development: Influences shaping engineering design and implementation in Nepal and the global village", Journal of International Development, Vol. 19 No. 1, pp. 123-144. https://doi/org/10.1002/jid.1353.

Nahapiet, J. and Ghoshal, S. (1998), "Social Capital, Intellectual Capital, and The Organizatinal Advantage", Academy of Management Review, Vol. 23 No. 2, pp. 242-266. https://doi/org/10.5465/amr.1998.533225.

Narayan, D. (2002), "Empowerment and Poverty Reduction", A Sourcebook. Edited by The World Bank, Washington. https://doi/org/10.1596/978-1-4648-0675-9. 
Narayan, D. and Cassidy, M. F. (2001), “A Dimensional Approach To Measuring Social Capital: Development And Validation Of A Social Capital Inventory”, Current Sociology, Vol. 49 No. 2, pp. 59-102. https://doi/org/10.1177/0011392101049002006.

Onwuegbuzie, A. J., Leech, N. L. and Collins, K. M. T. (2012), “Qualitative analysis techniques for the review of the literature”, Qualitative Report, Vol. 17 No. 28, pp. 1-28. https://doi/org/10.1007/s00784-018-2363-8.

Pansera, M. and Martinez, F. (2017), "Innovation for development and poverty reduction: an integrative literature review”, Journal of Management Development, Vol. 36 No. 1, pp. 2-13. http://doi.org/10.1108/JMD-02-20150013 Downloaded.

Pansera, M. and Sarkar, S. (2016), "Crafting Sustainable Development Solutions: Frugal Innovations of Grassroots Entrepreneurs”, Sustainability (Switzerland), Vol. 8 No. 51, pp. 3312-3317. https://doi/org/10.3390/su8010051.

Papanek, V. (1972), "Design for the Real World". BANTAM BOOK.

Pisoni, A., Michelini, L. and Martignoni, G. (2018), "Frugal approach to innovation: State of the art and future perspectives”, Journal of Cleaner Production, Elsevier Ltd, Vol. 171, pp. 107-126. https://doi/org/10.1016/j.jclepro.2017.09.248.

Della Porta, D. and Keating, M. (2008), "Approaches and Methodologies in the Social Sciences: A Pluralist Perspective”, In: D. Della Porta and M. Keating, Cambridge University Press, Cambridge. https://doi.org/10.1017/CBO9780511801938.

Prabhu, J. (2017), "Frugal innovation: Doing more with less for more, Philosophical Transactions of the Royal Society A: Mathematical”, Physical and Engineering Sciences, Vol. 375 No. 2095. https://doi/org/10.1098/rsta.2016.0372.

Prahalad, C. K. (2005), The Fortune at the Bottom of the Pyramid: Eradicating Poverty Through Profits, Pearson Education, Inc. https://doi/org/10.1017/CBO9781107415324.004.

Rao, B. C. (2013), “How disruptive is frugal?”, Technology in Society, Elsevier Ltd, Vol. 35 No. 1, pp. 65-73. https://doi/org/10.1016/j.techsoc.2013.03.003.

Richardson, B. and Callegari, N. (2008), "WIZZIT Mobile banking for the poor in South Africa", in sustainability challenges and solutions at the base of the pyramid. 1st. London. https://doi.org/10.4324/9781351279888.

Rogers, E. M. (1983), Diffusion of Innovations. 3rd edn.

Rosca, E., Arnold, M. and Bendul, J. C. (2017), "Business models for sustainable innovation - an empirical analysis of frugal products and services", Journal of Cleaner Production, Elsevier, Vol. 162, pp. S133-S145. https://doi/org/10.1016/j.jclepro.2016.02.050.

Rosca, E., Reedy, J. and Bendul, J. C. (2018), "Does Frugal Innovation Enable Sustainable Development? A Systematic Literature Review", European Journal of Development Research, Palgrave Macmillan UK, Vol. 30 No. 1, pp. 136-157. https://doi/org/10.1057/s41287-017-0106-3.

Schumacher, E. F. (1973), Small is Beautiful. https://doi/org/10.1038/nmeth.1895.

Seyfang, G. and Smith, A. (2007), "Grassroots innovations for sustainable development: Towards a new research and policy agenda”, Environmental Politics, Vol. 16 No. 4, pp. 584-603. https://doi/org/10.1080/09644010701419121.

Shekar, A. and Drain, A. (2016), "Community engineering: Raising awareness, skills and knowledge to contribute towards sustainable development”, International Journal of Mechanical Engineering Education, Vol. 44 No. 4, pp. 272-283. https://doi/org/10.1177/0306419016668966.

Simanis, E. et al. (2008), "The Base of the Pyramid Protocol Toward Next Generation BoP Strategy", Enterprise for a Sustainable World, Available at: http://www.bop-protocol.org/index.html.

Soydan, I. (2012), "Creating Frugal Innovations in India", Challenges for Western MNCs in Frugal Innovation process, pp. $1-64$.

UNDP (2008), “Creating value for all: strategies for doing business with the poor”. United Nations Development Programme.

Vallejos, R. V. et al. (2008), "Collaborative networks and social capital: A theoretical and practical convergence", IFIP International Federation for Information Processing, Vol. 283, pp. 43-52. https://doi/org/10.1007/978-0-38784837-2_5.

WBCSD (2004), "Doing business with the poor a field guide". World Business Council for Sustainable Development.

Weyrauch, T. and Herstatt, C. (2017), "What is frugal innovation? Three defining criteria", Journal of Frugal Innovation. Journal of Frugal Innovation, Vol. 2 No. 1, pp. 1-17. https://doi/org/10.1186/s40669-016-0005-y.

Whitehead, T., Evans, M. and Bingham, G. (2016), "Design Tool for Enhanced New Product Development in Low Income Economies", Design+Research+Society Future-Focused-Thinking, pp. 1-16.

World Bank (2018), "Nearly Half the World Lives on Less than \$5.50 a Day", Worldbank.Org. Available at: https://www.worldbank.org/en/news/press-release/2018/10/17/nearly-half-the-world-lives-on-less-than-550-a-day (Accessed: 7 March 2019).

Zeschky, M., Widenmayer, B. and Gassmann, O. (2011), "Frugal Innovation in Emerging Markets", ResearchTechnology Management, Vol. 54 No. 4, pp. 38-45. https://doi/org/10.5437/08956308X5404007.

\section{ACKNOWLEDGMENTS}

This research is carried out thanks to the financial support from the GRAND EST REGION FRANCE. 